ARTICLE

DOI: $10.1057 /$ s41599-018-0108-6

\title{
The vampirisation of the novel: narrative crises in Dracula
}

Cecilia Lasa ${ }^{1}$

\begin{abstract}
This article sets out to explore how Dracula narrates the crisis that the novel as a genre faces by the end of the nineteenth century. The fictional female characters play a particular role in such process: whereas the status of women in Bram Stoker's piece has been widely studied in terms of how their vampiric sexualisation affects their position in society and their relationships with men, there has been little analysis of their condition as writers and their relation to the novel as a genre. In Dracula, Mina Harker is a character who manages to record in her journal the events that unfold in the work of fiction, as well as her analysis of them. Similarly, her fiancé Jonathan Harker, the vampiric Count's solicitor, documents their adventures in order to keep some sanity in the light of the sexual, psychological and social disorder Dracula triggers. This chaos gains special significance in fin-de-siècle Great Britain, sieged by the decadence of the empire and the conflicts brought about by industrialisation. While Jonathan's accounts display features of the realist novel, Mina attempts to create a new narrative that entails a particular conception of the woman writer: a bourgeoning member of the middle class whose insights into reality are analytically critical and who incipiently acknowledges her sexual dimension, as suggested by the process of vampirisation she experiences. It is through writing that she becomes different from other highly sexualised vampires in the novel, namely her friend Lucy Westenra and the three women who inhabit the Count's castle. Mina's chronicles destabilise the novel as a form by proposing a new language for women and, specifically, for the woman writer. This proposal is one of the greatest threats that Dracula poses to the Victorian period through the use of the gothic. All male main characters in Stoker's piece put in constant effort to counter such menace. Given these men's success, Mina's writing does not thrive and, as the anticipatory note to the novel promises, a "sequence will be made manifest", which will realistically organise the events unchained by the vampire. In this way, both Mina's writing and Stoker's narrative, made up of fragments of different genres that can be nevertheless, appreciated as a whole, undergo an interrupted process of vampirisation.
\end{abstract}

\footnotetext{
${ }^{1}$ Facultad de Filosofía y Letras, Universidad de Buenos Aires, Buenos Aires, Argentina. Correspondence and requests for materials should be addressed to C.L. (email: cecilialasa@filo.uba.ar)
} 


\section{Introduction}

D ram Stoker's Dracula makes an exhaustive use of the vampire: this piece of fiction absorbs the unearthly being as an object of narration at the same time as it employs it at a formal level. Published in 1897, the novel presents readers with the vampiric eponymous count who plans to expand his territorial possessions, a process during which he displays supernatural powers, such as vampirising women whose bodies become more explicitly erotic. One of his victims is Lucy Westenra, a girl from an affluent family, constantly praised due to her beauty, who turns into a voluptuous creature as she falls under his influence. Her friend Mina Harker, a self-sufficient teacher who writes down how events in the novel unfold, is subjected to a similar attack. However, her process of vampirisation is interrupted because of the intervention of her fiancé Jonathan Harker, a promising solicitor who initially travels to Transylvania to assist Dracula in his purchase of property in London and falls prey to his villainy. After he escapes his imprisonment in the vampire's abode, he sets to hunt him down with the aid of Lucy's former suitors-Dr. John Seward, the American Quincey Morris, and the aristocratic Arthur Holmwood, who finally gains her favour-and of Abraham Van Helsing, the physician's ex teacher. The dispute clearly suggests a conflict between the evil aristocracy-Dracula's, not Holmwood's, a character who eventually receives the title of Lord Godalming and manages to inherit Lucy's property after her demise- and the free-thinking bourgeoisie led by Jonathan. A strategy this young man uses to wage that battle is to keep a written record of his stay in the castle: in order to survive the chaos unleashed by his aristocratic client, the lawyer writes a journal in which he jots down every factual piece of information so that he can retain his sanity. His travel narrative (Seed, 1985; Arata, 1990) is prosaic in two aspects: it is not in verse and it is related to his mundane experience. These two features, together with his social and economic status, make it possible to claim that his writing is analogous to the novel, a literary form that in England emerges in the eighteenth century, in keeping with the transition to a market economy detrimental to the patronage system (Watt, 1959; Eagleton, 2005) and the consolidation of the bourgeoisie (Lukács, 1971). Dracula is thus perceived as a threat to the most treasured genre of this social stratum; hence, the vampire becomes a formal device: he enfeebles such literary form by attacking its representatives, namely Jonathan as an exemplary narrator and, later, Mina.

Accordingly, Dracula relates narrative crises as the main characters engage in a contest to validate themselves as narrators. The budding professional Jonathan Harker endeavours to behave as an omniscient narrator who tries to make some sense of the chaotic environment which entraps him. However, Stoker's fiction foregrounds the solicitor's failure by sapping different genres to construct the object of narration: Jonathan's voice is not the only one authorised to tell the story. At the same time, it is through Mina Harker that the narrative conflict is reinforced. Analytically skilled, this young woman trains herself in the exercise of writing, first for her beloved and, afterwards, for the sake of enhancing her practice. Her drive to develop a more autonomous written production combines with an incipient sexual awakening associated with her transformation into a vampire. Based on her status as a freer woman writer, she espouses a new role model for women against the nineteenthcentury angel in the house, subservient to men (Woolf, 2008). Mina attempts to create a different narrative, which she manages to unfold by developing a new language once she starts to be vampirised. This gesture is the greatest menace Jonathan and his team have to combat with the purpose of upholding the novel: killing Dracula, responsible for his fiancée's conversion, becomes just the means to an end, which simultaneously reduces the threat of the return of the aristocracy to power. Consequently, assassinating the supernatural creature serves a double purpose when restoring the social and literary order: it averts the danger of the woman who writes and it curbs the formal experimentation of Stoker's collection of narrative voices. This double purpose is informed by a preliminary note, which anticipates that the multiplicity of points of view has been finally ordered. Mina and Dracula both devise narratives that contest the dominant form of the novel, though they undergo an interrupted process of vampirisation due to the endurance of the bourgeois male prose. This hypothesis will be studied by exploring three axes of analysis: the construction of the novel as a vampire, its defence in charge of the bourgeoisie and the threat of the woman writer.

The novel as a Vampire. Bram Stoker's Dracula engages in a problem of narration. As it tells about the adventures of a vampire and the group which chases it, the novel revolves around literature-specific concepts and processes such as the status of the narrator, the organisation of narrative material, the construction of verisimilitude, and the relation of the literary text to its context of production, as well as to its immediate context of reception. This complexity is evinced through the archival method by means of which the novel is composed, as summarised by Radick:

The story itself is presented as a series of documents. These include two journals kept in shorthand, a diary originally recorded on phonograph cylinders, letters, telegrams, memoranda, a ship's log, and newspaper clippings. For access and readability, transcriptions are made of the phonograph recordings and the short-hand is typed out. Other types of records are referenced throughout, including a notebook kept as a ledger, deeds, photographs, invoices and receipts, maps, and tombstones. (2013, p 507)

Different characters contest the efficiency of a single omniscient narrator and displace it by wording their points of views into a novel that absorbs their contributions to render its object of narration readable. Drawing upon a multiplicity of perspectives becomes a literary strategy to sustain the fiction about a mythical creature near the dawn of the 20th century. Similar to its eponymous protagonist-the vampire who sucks blood from his victims as a mechanism to nourish his existence, Dracula imbibes a wide variety of genres to inform its narrative and fuel it. Narration itself is thus subjected to a process of vampirisation: the novel, as such, becomes a vampire.

Hence, vampirism is not just a topic which answers the question of what Stoker's work is about: the vampire-its nature, its physiology-accounts for how different linguistic materials define Dracula as a novel. This conceptualisation is in keeping with what Eagleton states regarding the genre: "It cannibalises other literary modes and mixes the bits and pieces promiscuously together. [...] The novel is a melting pot, a mongrel among literary thoroughbreds". (2005, p 1) If that predatory hybridity is the distinguishing feature of this particular fictitious form, it remains unanswered where the relevance of equating Stoker's piece to a vampiric novel lies, especially when it is considered that the vampire has already become a "Gothic protagonist" in nineteenth-century fiction (Milbank, 2002, p 162). It is precisely such characterisation of this intriguing figure that hints at the answer since Gothic fiction, which emerges in the second half of the eighteenth century, is said to recover the anxieties of its historical time (Botting, 1996, p 1; Hurley, 2002, p 194; Punter and Byron, 2004, p 39; Senf, 2017, p 2). By the end of the Victorian era, a "crisis of belief" (Strandberg, 1964) emerges as a symptom of the loss of confidence "in England's national 
dominance or in the power of industrialism and science to create a better world" (Senf, 2017, p 2). This is a widespread feeling stemming from a context of increasing secularisation, urbanisation, industrialisation, demographic growth and agitation for workers' and women's rights (Guy, 2001). Due “to (Darwin's, Freud's and Marx's) scientific hypotheses of the nineteenth century [...], the modern Inferno has been created by a failure of belief -by a collapse of the old assumptions that [...] History is an arrow pointing onward and upward towards Infinite Progress" (Strandberg, 1964, p 477). The philosophical instability adds to the economic dimension of the conflict, as specified by Arata:

The decay of British global influence, the loss of overseas markets for British goods, the economic and political rise of Germany and the United States, the increasing unrest in British colonies and possessions, the growing domestic uneasiness over the morality of imperialism-all combined to erode Victorian confidence in the inevitability of British progress and hegemony. (1990, p 622)

Fiction does not remain impervious to the economic, social and political uncertainties and a literary crisis is unchained, which affects the novel as a genre. According to Watt, eighteenthcentury England witnesses a threefold cultural process that explains its rise: the development of cultural industries embodied in literary cafés and circulating libraries (1959, pp 42-43); the consolidation of the middle class, with leisure time to devote to reading ( $p p$ 43-46), a higher literacy rate than lower social orders (pp 39-40) and capital enough to acquire printed texts (pp 41-42); the obsolescence of the patronage system caused by the strengthening of the market and its laws (pp 53-56), which regulate the production, distribution and reception of written texts. Together with these changes, which underpin the formal transition from the romance to the novel, prose ousts verse: "The problem for poetry is that it seems increasingly remote from "life" as an industrial capitalist society is coming to define it" (Eagleton, $2005, \mathrm{p} 12$ ). The novel emerges as a more prosaic form in keeping with an incipient "Realism congenial to an ascendant middle class, with its relish for the material world; its impatient with the formal, ceremonial and metaphysical; its insatiable curiosity about the individual self; its robust faith in historical progress" ( $p$ 11). A novel such as Stoker's absorbs these contextual features through the introduction of an aristocratic protagonist who enervates bourgeois characters at will and extenuates them in order to satisfy his territorial expansion. This piece of fiction, however, is not just about a social and economic jeopardy; it is itself a literary menace since the novel as the eighteenth and nineteenth centuries have known it is in danger. The gothic thus becomes the means to voice this threat: as Dracula vampirises various historical aspects and different genres, its eponymous protagonist vampirises the bourgeoisie. This double vampirisation exposes the crisis of the prosaic literary form known as the novel.

Despite the threat, before the beginning of the narration, readers are told that the process of vampirisation has been averted. In fact, Dracula opens with a short paragraph with no title, which raises questions concerning the status of the narrative voice. As a preface or just a disclaimer, this anticipatory piece promises: "How these papers have been placed in sequence will be made manifest in the reading of them" (Stoker, 2000, n.p.). The use of the passive voice is not a desultory choice: it effaces the identity of the narrator as the voice which endows the material with narrative shape. What remains important is the shape itself, the "sequence". The effect is further reinforced by the subsequent sentence: "All needless matters have been eliminated" (n.p.). Regardless of who the narrator is, some narrative expertise is assured which renders the content of the novel readable, divesting it of unnecessary information. As far as the content itself is concerned, the paragraph acknowledges that it is "a history almost at variance with the possibilities of latter-day belief" (n.p.) and that it has been arranged so that it "may stand forth as simple fact" (n.p.).These assertions seem contradictory: a story about a vampire will meet with some resistance when proposed as factual in end-of-the-century London. By 1897, this capital city, where part of the novel unfolds, is the locus of Modernity, expressed in urban and industrial growth, as well as in imperial expansion: "as a world centre of economic and shipping activity, as the metropole of a growing empire and capital of Britain [...] London became the clearest spatial representation of Englishness" (Gilbert, 2004, p 13). A context where science and technology pervade everyday life privileges the realism that has incipiently emerged in eighteenth century England and "carried on traditional forms and viewpoints much longer, until far into the Victorian period" (Auerbach, 2003, p 491). Guy expands:

It should therefore come as no surprise that in defining their criteria of aesthetic value, the Victorians tended to judge a novel [...] primarily in terms of its representational qualities -that is, in terms of its verisimilitude or its ability to embody 'real life'. It followed from such a view that realism was the mode of writing [...] which the Victorians valued most, and that the novel [...] w[as] their most popular art-form. (pp 314-315)

The story about the notorious foreign count tallies little with modern life in London, where he intends to live, and the realistic literature which is favoured in the nineteenth century. This assail to verisimilitude notwithstanding, the initial note insists: "There is throughout no statement of past things wherein memory may err, for all the records chosen are exactly contemporary, given from the standpoints and within the range of knowledge of those who made them" (Stoker, 2000, n.p.). This short text remains adamant about the accuracy of the narration and, in order to preempt any objection to its content, it refers to a multiplicity of points of view which will uphold the narrative. Readers are told that such multiple perspectives may suggest a crisis of representation but the novel is still safe. This undefined section in Stoker's fictitious work assures the readership that the process of vampirisation will be arrested and realist prose will survive.

The formal deterrent against vampirisation which Dracula experiences means that the novel will not evolve into what can be termed, with hindsight, modernist fiction. Hurley theorises this relation:

Some of the most innovative works of fiction in the British anti-realist tradition can be found amongst popular genres-Gothic Horror, sensation fiction, science fictionat the fin de siècle. [...] They engage in narrative experimentation more consistently than their mainstream contemporary counterparts within the realist or naturalist tradition, foregrounding issues of narrativity, refusing to lay claim to narrative objectivity or omniscience, renouncing verisimilitude and narrative logic in favour of the production of sensation and affect. [...] Whether understood as proto-modernist or early modernist, the tradition instantiated by novels can be seen as on a continuum with such twentieth-century movements as 'high' modernism and surrealism. (2001, p 129)

The formal fracture associated with modernist modes of representation is a salient feature in Stoker's fiction, observable in the effacement of an omniscient narrator, replaced by multiple narrative points of views and in the breach with the modernity of reality. In fact, these traits make Dracula "the first great modern novel in British literature", according to Wicke (1992, p 467): 
I am turning the text to face forward into the twentieth century, rather than assessing its status as Victorian mythography $[\ldots]$. This is not to discount the probing and incisive readings that do annex Dracula to its very real Victorian contexts, but rather to shift the agenda in critical terms to the work that the text can do as a liminal modernist artefact, an exemplary text that then lies hauntingly behind the uncanny creations of modernism, at the borders of what is accepted as "high modernism," the high art tradition of its literature ( $\mathrm{p} 469$ ).

Although literary formal experimentation is undeniable, readers are promised a sequence by means of which sense is guaranteed. The novel becomes, as its protagonist, Un-Dead. It does expose the obsolescence and imminent death of the genre with its realistic prose. Yet, it does not fully unfold into a more typically modernist fiction since the process of vampirisation is deterred.

Fighting off vampires in defence of the novel. The adventure on which Jonathan, his fiancée and his "band of little men" (Stoker, 2000, p 315) embark has the aim of saving the novel as the prosaic expression of the bourgeoisie, which Dracula fears (Moretti, 1997, p 83). According to Watt, England witnesses the rise of the novel in the eighteenth century thanks to the "economic capacity of the middle class" (1959, p 42) that ensures its consolidation as a social group. Along these lines, Eagleton adds: "If it is a form particularly associated with the middle class, it is partly because the ideology of that class centres on a dream of total freedom from restraint" $(2005, \mathrm{p} 2)$. It is precisely such freedom that is at stake in Dracula: Jonathan's assistance of the Count on legal matters is tantamount to a total abdication of his liberty. Moretti specifies this problem:

He [the vampire] threatens the idea of individual liberty. For this reason the nineteenth-century bourgeois is able to imagine monopoly only in the guise of Count Dracula, the aristocrat, the figure of the past, the relic of distant lands and dark ages. Because the nineteenth-century bourgeois believes in free trade, and he knows that in order to become established, free competition had to destroy the tyranny of feudal monopoly (1997, p 93).

As a promising solicitor climbing up the social ladder, Harker reaches the supernatural being's castle and "enter[s] freely and of [his] own will” (Stoker, 2000, p 15). This condition reminds readers of the greatest values of the bourgeoisie-free will and the correlated notion of the self-made man-together with its aspiration of accessing the spheres of the aristocracy and its prerogatives. Paradoxically, those very same ideas are also responsible for his entrapment, which compromises the literary form he advocates.

The lawyer's imprisonment is literarily coded. Travelling East, to begin with, to meet the demands of the Count implies doctoring the coordinates of time and place upon which realistic verisimilitude is grounded (Watt, 1959, p 26). Departing from familiar England to unknown Transylvania to advise an unknown character thus unchains a narrative crisis, as it transpires through his travel writing. As a committed narrator, he registers his impressions to be later shared with his fiancée: "I was not able to light on any map or work giving the exact locality of the Castle Dracula, as there are no maps of this country" (Stoker, 2000, p 3). That abode is set in a desolate landscape in an uncharted territory, features which inscribe the novel in non-realistic modes of narration such as the gothic (Botting, 1996, p 2). By resorting to this fiction, Stoker's novel raises doubts as regards the category of space. Furthermore, once Jonathan is in the castle, he states:
Through these frowning walls and dark window openings [...] $[\mathrm{t}$ ]he time I waited seemed endless [...]. What sort of place had I come to, and among what kind of people? What sort of grim adventure was it on which I had embarked? Was this a customary incident in the life of a solicitor's clerk sent out to explain the purchase of a London estate to a foreigner? Solicitor's clerk! Mina would not like that. Solicitor, for just before leaving London I got word that my examination was successful, and I am now a full-blown solicitor! (Stoker, 2000, p 14)

The gloomy atmosphere is in keeping with the disintegration of time: the never-ending hours of waiting blur the temporal coordinate upon which verisimilitude is built. The disarticulation of time and place is not a simple formal whim: it is how a social crisis words itself into fiction. It comes as no surprise that, next to the distortion of those categories, Jonathan's concerns are mentioned: he is an ascendant member of a literate bourgeoisie, as witnessed by his newly acquired diploma. This juxtaposition is the literary device through which the economic world of the leading middle class clashes with a world that reminisces an old order-aristocracy-whose power has been reduced by the former. It is a non-realist narrative that narrates a social conflict, exposing the limits of the realist novel.

In this context, it is through writing that the growing solicitor fights against both Dracula, the character, and Dracula, the novel. Jonathan keeps a journal which, due to its prosaic form, is a resource to hold his world and achievements together. He states: "I have only the Count to speak with, and he-I fear I am myself the only living soul within the place. Let me be prosaic so far as facts can be. It will help me to bear up, and imagination must not run riot with me. If it does I am lost" (p 23). The young lawyer insists not only on the activity of writing but also on how it should be done: prosaically and rationally. As Seed summarises: "Harker constantly tries to normalise the strange into the discourse of the nineteenth-century travelogue, [a]s a defensive reaction to his voyaging into an unmapped area beyond the reach of train timetables" (1985, p 64). The solicitor insists on ordering the chaos that surrounds him, attributed to the decaying aristocracy (Stoker, 2000, p 23). He tries to behave as the omniscient narrator that Dracula undermines: his journal counterwrites the piece of fiction which absorbs it. Along these lines, following Lukács, (1971), p 75, Eagleton claims that the novel "must strive for sense and unity in an age when things no longer seem to harbour any inherent meaning or value" (2005, p 16). Dracula, the character, and Bram Stoker's text pose a thematic and formal threat to the prosaic arrangement of the world made by the middle class. In this light, the lawyer's writing is a bulwark against the vampirised novel and its vampiric protagonist, in defence of the realism of the prose of the bourgeoisie.

How the novel and its bourgeois supporters are placed in jeopardy is made explicit when Jonathan's sexuality is compromised. Senf, paraphrasing Hurley, (2002, p 194), states: "the Gothic emerges during periods of genuine psychic crisis" (2017, p 6). In Dracula, vampirisim presents alternative sexualities to the socially accepted monogamous heterosexual paradigm of the nineteenth century, which destabilises the solicitor's psychological arrangement. In the gothic castle, homoeroticism is implied in a scene in which the young man is shaving:

I had cut myself slightly [...] and the blood was trickling over my chin. [...] When the Count saw my face, his eyes blazed with a sort of demoniac fury, and he suddenly made a grab at my throat. I drew away and his hand touched the string of beads which held the crucifix. It made an instant 
change in him, for the fury passed so quickly that I could hardly believe that it was ever there (Stoker, 2000, p 23).

Attracted by Jonathan's blood, Dracula approaches his guest through a movement which binds them in a highly erotic proximity, arrested by a synecdoche of an institution-religion-which has historically condemned homosexuality. It is only after this close encounter that Jonathan explicitly confirms his status as a prisoner (p 24). Such juxtaposition suggests that the Count's homoerotic drives seem to act to the detriment of his freedom as the most celebrated value of the bourgeoisie. Under these circumstances, a realist prose emerges as a mechanism against social, economic and sexual chaos, as it is evinced by the solicitor's reflection on how he should keep both his sanity and his journal: he wishes he "could put down all he said exactly as he said it" (p 25) and he insists on narrating "so many strange things" (p 23) by "begin[ning] with facts". However, Jonathan is compelled to forsake the factual accuracy as a defining feature of his status as a prosaic writer of the bourgeoisie. Actually, the aristocratic vampire dictates to him what to write and how to do it: he must "not discourse of things other than business in your letters" ( $\mathrm{p}$ 28) and must let his "friends [...] know that [he is] well" (p 28). He is even asked to tamper with dates, therefore altering the time coordinates that are the pillars of formal realism (Watt, 1959, p 26):

The Count asked me [...] to write three letters, one saying that my work here was nearly done, and that I should start for home within a few days, another that I was starting on the next morning from the time of the letter, and the third that I had left the castle and arrived at Bistritz. I [...] felt that in the present state of things it would be madness to quarrel openly with the Count whilst I am so absolutely in his power [...] and asked him what dates I should put on the letters. He [...] said, 'The first should be June 12, the second June 19, and the third June 29.' (Stoker, 2000, pp 35-36)

The realist narrator is requested not to be factual: the content of his letters does not coincide with his experience nor are the time references real. The budding middle-class member has finally desisted from his attempts to organise the world and a narrative faithful to it. This halt is shown by the adoption of a writing mode which opposes the formal realism that accompanies the emergence of the eighteenth-century English novel as a genre and its consolidation in the nineteenth century. Vampirism in Stoker's novel, then, presents homosexuality as a threat to freedom as the key value of the bourgeoisie and also as a menace to its correlative literary form, the realist novel.

An interrupted orgy between Jonathan and three female vampires provides a further instance of the ways in which vampiric alternative sexualities destabilise the psychology of the middle-class narrator and his prose. The young lawyer acknowledges their "deliberate voluptuousness which was both thrilling and repulsive" (p 33). The scene is overtly erotic in content, as can be summarised in the action performed by one of the vampires: she is "fairly gloating" ( $\mathrm{p}$ 33). This encounter with multiple sexual partners, which seems to enact "some dreamy fear" (p 33), is halted by Dracula, who commands the female creatures to desist, despite their complaints (pp 34-35). The scene recovers some "clichés w[hich] have some basis in truth or practice" (Guy, 2001, p 463) as regards Victorian sexual relations, such as "a refusal to acknowledge the existence of unconventional sexualities" ( $p$ 465). Similar to its treatment of homoeroticism, Dracula presents the orgy in terms of horror. After the Count has told off the three female supernatural beings, Jonathan acknowledges: "Then the horror overcame me, and I sank down unconscious" (Stoker, 2000, p 35). Alternative modes of experiencing sex deprive him of the consciousness needed to observe, register and analyse: they strip the bourgeois narrator of the necessary skills to sustain his prosaic way of writing, attached to facts. The vampires embody sexual behaviours condemned by the nineteenth-century norms which make Jonathan undergo an experience beyond the factual. He finds himself unarmed to fight off this threat, as later expressed through the sick condition he develops while imprisoned. The vampiric sexual encounters in the castle have drained the middle-class solicitor of his vital energy, once the aristocratic owner has sufficed his own needs. Dracula vampirises the promising young man and so exsanguinates the realist prose of the novel. What is left is a weakened member of the bourgeoisie, as weakened as the literary genre he represents and the writing he endorses.

The real threat: the woman writer. The narrative crisis in Dracula, however, is not only unchained by an alien force but also by an internal agent: the woman who writes. In fact, two women exercise that practice in Stoker's novel: Lucy and Mina. The two young friends exchange letters, though it is only Jonathan's fiancée who manages to publish her journals while alive to an audience made up of the male team that wants to annihilate the vampiric threat. Despite this difference, both girls make an incipiently subversive use of writing that challenges the alleged purpose of this activity in nineteenth-century Great Britain: they replace the social function that postulates writing "as a form of moral instruction" (Guy, 2001, p 314) with a conception of writing as the expression of freedom.

As far as Lucy is concerned, she writes as a mechanism to release repressed sexual desires. She confesses to Mina after having been proposed by Holmwood, Quincey and Dr. Seward: "Why can't they let a girl marry three men, or as many as want her, and save all this trouble? But this is heresy, and I must not say it" (Stoker, 2000, p 51). Through her written complaint, she lets her friend know about her multiple sexual attraction. Immediately, she reprimands her words, aware of "sexual morals which [...] condemned female sexual appetites" (Guy, 2001, p 464). Her truth cannot be written, unlike Jonathan's, as he does not hesitate when writing about "some longing and at the same time some deadly fear" (Stoker, 2000, p 33) for the three vampires who approach him while locked in Dracula's castle: "I felt in my heart a wicked, burning desire that they would kiss me with those red lips. It is not good to note this down, lest some day it should meet Mina's eyes and cause her pain, but it is the truth" (p 33). Acknowledging sexual desire through writing seems to be a male prerogative: "double standards [...] exonerated male promiscuity" (Guy, 2001, p 464). It is this privilege that Lucy's epistolary prose challenges when she poses a threat to sexual mores, as well as to a style of writing which is expected not to subvert the status quo. She rejects art's "primary function of [...] socialis[ing] individual readers $[\ldots]$ into the moral values of their culture" (p 314). This young woman contests that function, which renders her liable to vampirisation: her polyandric thirst and writing about it are already perceived as unnatural. This process is the visible sign of her double menace: she discloses a sexuality not admitted for women and a type of writing which does not intend to reproduce the conventions that hold the social order together. By means of her written word, Lucy exposes what that order represses to be kept as such.

In addition, Lucy's menace undermines gender stereotypes of the English nineteenth century, an action which is also coded in her transformation into a vampire. She conceives of sexuality in terms of the pleasure that it allows her to experience, not in biological terms-a necessary dimension to reproduce the species. 
This relation between women and sexuality taints the purity bestowed upon those who are expected to behave as "the angel in the house", thus characterised by Woolf:

She was intensely sympathetic. She was immensely charming. She was utterly unselfish. She excelled in the difficult arts of family life. She sacrificed herself daily [...]-in short she was so constituted that she never had a mind or a wish of her own, but preferred to sympathise always with the minds and wishes of others. Above all [...] she was pure. Her purity was supposed to be her chief beauty. (2008, p 141)

The purity attached to femininity deprives women of independence of thought and desire. This subservience is at stake through Lucy's writing and her later vampiric conversion. Both her written expression, as well as her vampirisation share an element of subversion since they question the expectations about women's behaviour and sexuality. When she becomes an UnDead, she unequivocally rejects the figure of the angel in the house: as a vampire she fulfils what she has started to explore as a woman writer. As Senf notes (1982, p 46), once a supernatural creature, she chases and scares off children (Stoker, 2000, p 146); she does not bear them: Lucy is neglecting "the difficult arts of family life". It is only after having died that she can set her sexuality free of social mandates. She is subjected, though, to a second death, because her vampirisation is an act of rebellion against the angelical and pure beauty which women are expected to bear, even when they are dead. Lucy's suitors and Van Helsing begin to sense this threat before her demise: while she is still alive, her transformation creates "a nightmare of Lucy [...], the pointed teeth, the blood stained, voluptuous mouth, which made one shudder to see, the whole carnal and unspirited appearance, seem [s] like a devilish mockery of Lucy's sweet purity" (p 178). However, what is most disturbing is the public acknowledgement that the lack of purity can also be beautiful, as Dr. Seward thinks of the Count's victim when she is already a vampire: “There lay Lucy, seemingly just as we had seen her the night before her funeral. She was, if possible, more radiantly beautiful than ever, and I could not believe that she was dead. The lips were red, nay redder than before, and on the cheeks was a delicate bloom" ( $p$ 166). These words celebrate a conception of beauty which opposes the pure angel in the house: the model of women Mina's friend is proposing is even more luring than the angelic purity. This threat has to be dispelled as well:

There, in the coffin lay no longer the foul Thing that we had so dreaded and grown to hate [...], but Lucy [...] with her face of unequalled sweetness and purity. [...] One and all we felt that the holy calm that lay like sunshine over the wasted face and form was only an earthly token and symbol of the calm that was to reign for ever. (p 180)

Lucy's second death is a restoration of a specific gender stereotype-the mild and weak woman necessary to keep the social mores that silence women's desire and guarantee male dominance. Both writing and vampirisation have allowed Lucy to explore her sexual desires beyond cultural mandates. Her first death into the world of the Un-Dead does not curtail the freedom she achieves through writing: becoming a vampire is just a continuity of a process of liberation that has already begun. Holmwood, Quincey and Dr. Seward, led by Jonathan and Van Helsing, kill this freedom. In assassinating what they conceive of as the fin-de-siècle femme fatal, these men annihilate the trace of a woman who has written her unconventional desires.

It is Mina, however, who forwards a narrative crisis. A bourgeoning member of the literate middle class, she manages, unlike Lucy, to remove her written production from the sphere of intimacy by having men read her journals. The writings of this assistant schoolmistress extend far beyond her own sphere of reference. Initially, however, her contributions are subsidiary to his fiancé's job:

I have been working very hard lately, because I want to keep up with Jonathan's studies, and I have been practicing shorthand very assiduously. When we are married I shall be able to be useful to Jonathan, and if I can stenograph well enough I can take down what he wants to say in this way and write it out for him on the typewriter, at which also I am practicing very hard. (p 46)

Though she does not first think of writing in autonomous terms, she gradually develops some concerns that exceed its utilitarian value:

I do not suppose there will be much of interest to other people, but it is not intended for them. [...] [I]t is really an exercise book. I shall try to do what I see lady journalists do, interviewing and writing descriptions and trying to remember conversations. I am told that, with a little practice, one can remember all that goes on or that one hears said during a day. (pp 46-47)

The exercise to which she makes reference is that of becoming a writer. She is in pursuit of female precursors who can provide her with some sense of reference to guide her when undertaking the task of writing beyond its utility for men. Mina is mindful of writing methods, regardless of how useful the outcome is for others' purposes. This search constitutes her as a woman writer. Gilbert and Gubar thus define this concept:

the loneliness of the female artist, her feelings of alienation from male predecessors coupled with her need for sisterly precursors and successors, her urgent sense of her female audience together with her fear of the antagonism of male readers, her culturally conditioned timidity about selfdramatisation, her dread of the patriarchal authority of art, her anxiety of the impropriety of female invention-all these phenomena of "inferiorization" mark the woman writer's struggle for artistic self-definition and differentiate her efforts at self-creation from those of her male counterpart. (2000, p 50)

Mina's struggle is, in this light, twofold. On the one hand, as a member of the rising bourgeoisie, she must fight the danger of the Transylvanian Count who attempts to establish an old aristocratic social order and threatens her class identity. On the other hand, unlike Jonathan, Mina cannot simply adopt prose writing as a strategy to battle such menace since that mode also advocates male supremacy. She thus needs to create a different form of writing to record facts. Consequently, she resorts to journalism written by women as an alternative style to chronicle her adventures more faithfully. These needs exhibit the limits of the eighteenth and nineteenth-century novel, which unchains the crisis of narration: the bourgeois literary form does not allot a place for a woman to write autonomously.

The narrative Mina endorses entails a different conception of the woman as a member of society. She herself makes allusion to this alternate role model, the new woman:

Some of the 'New Women' writers will some day start an idea that men and women should be allowed to see each other asleep before proposing or accepting. But I suppose the 'New Woman' won't condescend in future to accept. She will do the proposing herself. And a nice job she will make of it too! There's some consolation in that. (Stoker, 2000, p 75) 
The young woman's thoughts seem to curb her rebellion: she challenges the mores prescribed by the institution of marriage without questioning the institution itself. Nevertheless, the final assertion suggests discomfort with this compromise: seeking solace hints at some uneasiness which will not be solved by simply being given the possibility of proposing marriage. Her concerns go beyond the expected married life: she actually does not allude to new women in general; instead, she makes specific reference to the new women who write. Writing is then the real problem. Therefore, the disquiet she experiences can be read as a symptom of what Gilbert and Gubar conceptualise as "anxiety of authorship" (2000). This concept is a reappropiation and relaboration of that coined by Bloom, "anxiety of influence" (1997, p 50), which accounts for the construction of the male literary writer: "Bloom has postulated that the dynamics of literary history arise from the artist's "anxiety of influence," his fear that he is not his own creator and that the works of his predecessors, existing before and beyond him, assume essential priority over his own writings" (Gilbert and Gubar, 2000, p 46). The two critics state that "Bloom's male-oriented theory of the "anxiety of influence" cannot be simply reversed or inverted in order to account for the situation of the woman writer" (p 48). What a woman who writes experiences is "a radical fear that she cannot create, that because she can never become a "precursor" the act of writing will isolate or destroy her" (p 49). In the case of Mina, her anxiety of authorship stems from the fact that, to define herself as an autonomous writer, she must simultaneously define herself as an autonomous woman.

In Mina's struggle, it is through writing that she constructs herself as a woman and it is through the experience of being a woman that her writing becomes different from men's-Jonathan's, particularly. By writing autonomously, she dismisses the role model she has inherited:

And when I came to write I encountered her with the very first words. The shadow of her wings fell on my page; I heard the rustling of her skirts in the room. [...] And she made as if to guide my pen.

[...] It is far harder to kill a phantom than a reality. She was always creeping back when I thought I had despatched her. Though I flatter myself that I killed her in the end, the struggle was severe [...]. But it was a real experience; it was an experience that was bound to befall all women writers at that time. Killing the Angel in the House was part of the occupation of a woman writer. (Woolf, 2008, pp 141-142)

By means of an autonomous writing, the young woman has started to kill the angel in the house. She seems to be partially aware of the process she is undergoing, as it is shown by the little joke she plays on Van Helsing when submitting to him a text she knows he will not be able to read:

I could not resist the temptation of mystifying him a bit-I suppose it is some taste of the original apple that remains still in our mouths, so I handed him the shorthand diary. [...]

'Oh, you so clever woman! [...] And will you not so much honour me and so help me as to read it for me? Alas! I know not the shorthand.' By this time my little joke was over, and I was almost ashamed. So I took the typewritten copy from my work basket and handed it to him. (Stoker, 2000, p 152)

The schoolteacher thinks of her action in terms of sin: when presenting herself as a knowledgeable writer, she exposes men's poor reading. She is not abiding by the commands dictated by the angel in the house regarding how to relate to men: "Be sympathetic; be tender; flatter" (Woolf, 2008, p 141). She distances herself from the expected gender roles by remaining impervious to the expected dependence on men both when writing and when publishing her production.

As a woman who writes and publishes, Mina also emerges as an insightful reader: this three-dimensional condition challenges the male supremacy that regulates her world. In fact, she is the cornerstone upon which the hunting of the vampiric Count is organised. Van Helsing acknowledges her importance at the same time as he belittles her: "She has man's brain [...] and a woman's heart" (Stoker, 2000, p 195) Mina seems to have started her transformation into a supernatural creature even before Dracula attacks her: her intelligence is thought of as not natural to a woman. Gilbert and Gubar account for a response of this type, which contributes to the woman writer's anxiety of authorship: "Her battle, however, is not against her (male) precursor's reading of the world but against his reading of her. In order to define herself as an author she must redefine the terms of her socialisation" (2000, p 49). In spite of the gender stereotypes perpetuated by a male-dominated society, a discerning woman writer is not unnatural: she can be part of the real sphere, which is a requirement for Mina to authorise herself, as well as her writing. She accomplishes this objective by means of what realist prose celebrates the most: facts. Her detailed register of the Count's movements and habits makes her a sophisticated reader. This schoolteacher is indeed the one who shows an understanding and reads the perils associated with the aristocratic vampire: "Count Dracula's problem is to get back to his own place" (Stoker, 2000, p 292). Unlike Lucy -a self-centred woman writer, concerned about her love-related predicament, Mina manages to verbalise the cultural anxieties the gothic embodies: the vampire undermines homeland security. She provides reading instructions as to how to fathom the conflict and tackle it: if Dracula has problems in returning to his place of belonging, that becomes a problem for the English people, since their lands will suffer the terror of his command. Her words may as well explain Morris's death by the end of the novel: having joined Jonathan in defence of the bourgeoisie, this ambassador of the country of free entrepreneurship, which since its independence has been contesting England's world supremacy, "must die, because Morris is a vampire" (Moretti, 1997, p 95). Like the Transylvanian supernatural being, "shrouded in mystery [...] Morris has been round the world [...]; he would like to replace him [Dracula] in the conquest of the Old World. He does not succeed in the novel but he will succeed, in 'real' history, a few years afterwards [...] because America will end up by subjugating Britain [...] and Britain is, albeit unconsciously, afraid of it" (pp 95-96). These implications derived from Mina's speech expose nationalist anxieties about what Senf calls "reverse imperialism": "the threat of the primitive trying to colonise the civilised world" (1988, p 164). Arata elaborates on Mina's analytical insight by working on the concept of "the anxiety of reverse colonisation":

As Van Helsing says, vampires follow "in [the] wake of" imperial decay ( $p$ 286). Vampires are generated by racial enervation and the decline of empire, not vice versa. They are produced, in other words, by the very conditions characterising late-Victorian Britain. [...] Dracula's move to London indicates that Great Britain, rather than the Carpathians, is now the scene of these connected struggles. The Count has penetrated to the heart of modern Europe's largest empire. (1990, p 629)

Dracula purchases property in London because it is the capital of the system that, though obsolete in some other countries in Europe, still holds and presents itself as the basis of imperialism: monarchy. As a member of the bourgeoisie, Mina denounces the 
possible return to power of the aristocracy by suggesting specular images between imperial Great Britain and imperial Dracula. In coming to the core of the empire, the supernatural figure "mirrors the domestic practices of Victorian patriarchs, so his invasion of London in order "batten on the helpless" natives there mirrors British imperial activities abroad" (p 633). The schoolteacher reveals that her condition as a woman writer is built together with her status as a shrewd reader who can clearly identify the conflict Stoker's novel presents.

Mina's insight succeeds in binding both the supernatural and the natural worlds, which turns her into the woman journalist she has longed to be. Her records and her subsequent analysis allow her to see Dracula as the double of Western imperial politics. According to Freud, the double "[f]rom having been an assurance of immortality, it becomes the uncanny harbinger of death" (2003, p 142). This double movement becomes visible in the aristocratic vampire's territorial expansion: expansionism has been the mechanism Great Britain has used to build itself as an empire, as well as the mechanism employed by the colonised to become perpetrators, endangering the imperial project which, by the decline of the nineteenth century, shows signs of desuetude. The presence of the Count in London evinces that imperial politics backfires. Along these lines, Senf (1979, p 164) and Arata (1990, p 631) have identified similarities between Jonathan and Dracula since both represent their mutual condition of existence and destruction. Dracula needs the English language and the knowledge of the solicitor to acquire property in a world in which the aristocracy is decaying and the middle class is consolidating its power. In the same way, Jonathan needs to provide this service to climb up the social ladder and enjoy the prerogatives once restricted to upper social orders, which imperils him. Mina also hints at this parallelism, which reinforces the relevance of the notion of the double:

'The Count is a criminal and of criminal type. [...] His past is a clue, and [...] tells that once before, [...] he went back to his own country from the land he had tried to invade, and thence, without losing purpose, prepared himself for a new effort. He came again better equipped for his work, and won. So he came to London to invade a new land. He was beaten, and when all hope of success was lost, and his existence in danger, he fled back over the sea to his home. [...] Then, as he is criminal he is selfish. And as his intellect is small and his action is based on selfishness, he confines himself to one purpose. (Stoker, 2000, p 285)

The words of the newly born journalist seem to be referring to both Count's and Jonathan's-and his team's-determination.

The woman writer becomes a threat to male supremacy, both in the middle and upper social orders. However, is it the aristocratic supernatural villain who promises revenge against Mina's intelligence once she has disclosed his strategy:

And so you, like the others, would play your brains against mine. You would help these men to hunt me and frustrate me in my design! [...] And you, their best beloved one, are now to me, flesh of my flesh, blood of my blood, kin of my kin, my bountiful wine-press for a while, and shall be later on my companion and my helper. You shall be avenged in turn, for not one of them but shall minister to your needs. But as yet you are to be punished for what you have done. You have aided in thwarting me. Now you shall come to my call. When my brain says 'Come!' to you, you shall cross land or sea to do my bidding. (pp 239-240)

Dracula fears Mina's analytical insight and he punishes her by, predictably, controlling her brain -the locus of her intellectual activity. This punishment takes place after the scene in which, in
Case's understanding (1993, p 233), the vampire rapes the young writer by forcing her to suck his blood (Stoker, 2000, p 234). She seems to be a woman who does no pay blind obedience to him, unlike Lucy and the female vampires in his castle. Mina's rebellion is through writing, understood as a practice that reaches the social and public realm. This distances her from Lucy, whose writing is reduced to the private sphere, and from the three women in Dracula's abode, who do not seem to write at all. The terms of socialization Mina is subverting by becoming one of those "lady journalists" ( $p$ 46) are the buttresses that uphold male hegemony, both in her real middle-class world, as well as in the non-real aristocratic one.

Embodying such a threat, it comes as no surprise that the novel narrates that danger, again, as a process of vampirisation. This characterisation seems to confirm Arata's observation that "fear of women is never far from the surface of [Stoker's] novels" (1990, p 625) even though "Dracula alone cannot give a full sense of either the range of Stoker's interests or of the pressures and contexts [which include gender concerns] that conditioned the creation of his most famous novel" (Hopkins, 2007, p 1). What is palpable in Mina as a fictional character is that her transition intensifies her anxiety of authorship as a woman writer:

'And I,' said Mrs. Harker brightly, and more like her old self than she had been for many a long day, 'shall try to be of use in all ways, and shall think and write for you as I used to do. Something is shifting from me in some strange way, and I feel freer than I have been of late!' The three younger men looked happier at the moment as they seemed to realise the significance of her words. But Van Helsing and I, turning to each other, met each a grave and troubled glance.

(p 282)

Mina cannot identify the nature of the changes she is undergoing as it is seen in the use of the indefinite pronoun "something" and the vagueness of the expression "in some strange way". She is about to become a woman who will merge autonomous writing with the possibility to enjoy body pleasures due to the conversion which will sexually release her. She seems to know, though, that those features are related to some freedom she cannot relish under her current circumstances, through "her old self". Freedom in terms of the exercise of sexuality and of intelligence by means of the written word is what endows the situation with strangeness and lack of definition. While her older writing self is subservient to men, Mina's new self is shifting from that position. Readers are witnessing the birth of a new woman, a redefinition which male figures fear: a woman who outsmarts the most literate men and, at the same time, undertakes the path of sexual freedom. This liberty is the real threat for the bourgeoisie and its favourite literary form-the novel. This process also affects the schoolteacher's anxiety of authorship as a woman writer as Dr. Seward notices:

When she did speak, her words were enigmatical. [...] She stopped and a shudder ran through her, increasing in intensity for a few seconds, till at the end, she shook as though in a palsy. She said no more [...]. When she woke from the trance, she was cold, and exhausted, and languid, but her mind was all alert. She [...] asked what she had said [...], she pondered over it deeply for a long time and in silence. (p 288)

Mina develops a different language once she starts to combine in herself the clever woman who reads insightfully and writes autonomously with the one who begins to experience a sexual awakening, as later confirmed by Dracula's vampires who invite her to join their sisterhood ( $p$ 306). The men in the novel cannot understand her spoken words nor her silences, which is why they 
qualify this language as "enigmatical" or think of it as an expression of a trance. A new linguistic modality is emerging for the woman writer in relation to a new conception of women altogether.

As a woman who writes, Mina has now placed in jeopardy the real and the non-real worlds, as her increasing vampirisation evinces a transition which, as readers have been promised, will be averted. If her writing and sexual independence are the real threat to Victorian England, why do Jonathan and his team not attack her directly, even after having confessed to their apprehensions of the schoolteacher's enigmatical language? They manage to neutralise her by leaving her out of the adventure of hunting Dracula down under the excuse of protecting her from the vampire, who has verbalised his own fear of her intelligence. The subsequent assault by the Count provides Jonathan and his team with the reason to try to annihilate him. The subterfuge has become clear now: countering the foreign menace is the means to combat the internal threat posed by the freedom of the woman writer, who has started as well a process of sexual initiation. Such casuistry is made explicit by the strategy designed by the leader of the hunting group:

I am so glad that she consented to hold back and let us men do the work. Somehow, it was a dread to me that she was in this fearful business at all, but now that her work is done, and that it is due to her energy and brains and foresight that the whole story is put together in such a way that every point tells, she may well feel that her part is finished, and that she can henceforth leave the rest to us. (p 206)

Mina's achievements, which result from her collating the material to locate and annihilate the vampiric Count, act to her detriment: the passion, the intelligence and the sagacity with which she has developed her writing are turned into the cause of her own doom by men who have left her to her own devises, making her an unprotected victim of Dracula. Dr. Seward confirms this specious scheme: "One thing I know, that if my instinct be true regarding poor Mrs. Harker's silences, then there is a terrible difficulty, an unknown danger, in the work before us. The same power that compels her silence may compel her speech" ( $p$ 268). The language she has constructed when becoming a woman writer becomes "an unkownn danger" for men. This figure is radically different from the one Jonathan imagines while trapped in Transylvania:

Here I am, sitting at a little oak table where in old times possibly some fair lady sat to pen, with much thought and many blushes, her ill-spelt love letter, and writing in my diary in shorthand all that has happened since I closed it last. It is the nineteenth century up-to-date with a vengeance. And yet, unless my senses deceive me, the old centuries had, and have, powers of their own which mere 'modernity' cannot kill (pp 31-32).

When the middle-class solicitor relates women to writing, he can only think of the model Lucy represents before becoming a vampire: a non-professional angel in the house who scribbles love letters to other angels. Mina's writings, on the contrary, reach a wider audience, which includes men, and tackle social and cultural issues. Jonathan and his team conceive of this as a disease, a negative effect of having fallen prey to Dracula. Through this casuistry, the group of men taints her skills with villainy and paves the way for their intervention to rid themselves of the external threat of the aristocracy and the internal threat of a free woman writer. Modernity becomes a prerogative of the male bourgeoisie and does not imply any revision of gender roles, which may benefit women, in general, and the woman writer, in particular.
This is the work before them: Jonathan, Holmwood, Quincey, Dr. Seward and Van Helsing have the task of safeguarding the angel in the house. In killing Stoker's vampire thanks to Mina's journals, they kill the woman writer who, due to her vampirisation, is about to start to derive pleasure from her sexuality. As Senf summarises:

By emphasising Mina's intelligence, her ability to function on her own, and her economic independence before marriage, Stoker stresses certain aspects of the New Woman; but by negating her sexuality, having her adopt a more traditional feminine role, and by showing her decision to abide by the group's will instead of making an individual decision, he also reveals that she is not a New Woman. (1982, p 48)

This double movement is first foreshadowed by the moment Mina marries a hardly convalescent Jonathan ( $\mathrm{p} \mathrm{88)}$. Sexual life is placed in the background and only present for reproductive purposes. Mina's sexuality is not different from Lucy's, as Arata claims:

Once separated from that [motherly] function, as Lucy's desire is, female sexuality becomes monstrous. The violence of Lucy's demise is grisly enough, but we should not miss the fact that her subjection and Mina's final fate parallel one another. They differ in degree, not kind. By the novel's close, Mina's sexual energy has been harnessed for purely domestic use. In the end, women serve identical purposes for both Dracula and Western characters. [...] Dracula's biological colonisation of women becomes a horrific parody of sanctioned exploitation practiced by the Western male (1990, pp 632-633)

By linking Mina to Lucy, Arata aligns himself with Roth, who claims: "Lucy and Mina are essentially the same figure" (2010, p 30), the woman who has been sexualised. Arata, however, distances himself from Roth's conclusion: "Lucy is destroyed and Mina saved" (p 34). If Jonathan's fiancée is assessed in the light of the complexity she has developed throughout the novel, she has not been saved: the woman who combines her intelligence and sexuality has been destroyed. What is left is a "much less sexually threatening" (pp 30-31) person, which does not necessarily mean that Mina as a woman writer has not been destroyed. That the schoolmistress has been finally colonised, in Arata's terms, is evident in her becoming a mother after Dracula has symbolically raped her (Case, 1993, p 233) and after the consummation of her marriage with her husband. She has subdued to male supremacy, as it is confirmed by naming her baby after all the men that have participated in the assassination of the vampire (Stoker, 2000, p 315). Thus, Mina has born the child of those who have annihilated the alternative writing she has endorsed. This form of maternity silences the woman writer and restores the angel in the house.

Mina's restoration parallels that of Dracula. Both the character and the novel have been subjected to a process of vampirisation and in both cases their transformation has been averted. The promise of a clear narrative sequence has been kept because the woman writer-who has challenged the dominant prose and purported a new narrative voice- has been spuriously defeated with her own weapons (Wicke, 1992, p 467, p 476). In the same way as the vampire hunters are collected in the name of the schoolteacher's baby, the wide variety of sources which nourish the Stoker's fiction is eventually collated by one final predominant narrator. Unlike the polyphony that articulates Dracula, there emerges a final note, omnisciently narrated by Jonathan, which confirms that the initial engagement has not been broken:

In the summer of this year we made a journey to Transylvania $[. .$.$] . Every trace of all that had been was$ blotted out. [...] 
When we got home we were [...] struck with the fact that in all the mass of material of which the record is composed, there is hardly one authentic document. Nothing but a mass of typewriting, except the later notebooks of Mina and Seward and myself, and Van Helsing's memorandum. We could hardly ask anyone, even did we wish to, to accept these as proofs of so wild a story. (Stoker, 2000, p 315)

The male bourgeoisie and its most acclaimed literary genre have triumphed. The prosaic narrator has mastered the conflict, as it is shown by his uneventful journey to the foreign land once inhabited by the external threat to his social group with the company of the woman who, as an internal menace, has contested his narrative authority. Moretti explains: "The firstperson account is a clear expression of the desire to keep hold of one's individuality, which the vampire threatens to subjugate" (1997, p 98). Once the supernatural being has been removed, there no longer seems to be any sign of danger. The voice of Van Helsing, "born in that other classic homeland of free trade, Holland" (p 93), validates the restoration of order at the end of the novel, though Arata insists: "The cost of such assurance is great, however. Quincey Harker stands as a mute reminder of the violence upon which stability of the nation, as well as the family, rests" (1990, p 643). This stability is the result of traces that have been blotted out by Jonathan's monophonic narrative voice, aided by Van Helsing, who has also "counteract[ed] the fragmenting effects of the narrative" (Seed, 1985, p 71). Those traces refer not only the topic of the novel-a vampire and the chaos he has unleashed-but also to the signs of a new form of writing that has been obliterated: a vampiric writing in charge of a vampiric woman. Left as a benchmark of verisimilitude is the whole narrative sequence, the narration itself. Dracula is a novel whose process of vampirisation has been averted and, likewise, Mina's transformation into an autonomous woman writer who relishes her sexuality has been interrupted.

Final reflections. Stoker's most renowned piece manages to present thematic content which revolves around a vampire and, at the same time, the novel formally becomes a vampire itself. Dracula absorbs economic, social, sexual and literary problems as it imbibes different genres and narrative voices to shape a narration in keeping with the "latter-day belief" (Stoker, 2000, n.p.). As nineteenth-century Great Britain has to address domestic issues such as workers' and women's agitation in the context of industrialisation, the country also bears witness to the decay of its empire and it undergoes a crisis of belief which undermines long established notions, such as unavoidable historical progress. The vampiric protagonist is a gothic creature who embodies those cultural anxieties and emerges as the threat for the members of the bourgeoisie who perceive in him the menace of the restoration of a vanquished previous order. The social complexity correlates to a narrative complexity, since the Irish writer's work saps a wide variety of genres with the ensuing effect of devitalising an omniscient narrator who can organise the content of the novel. This literary form has started its process of vampirisation, which will be deterred by the social group which has tightly embraced it-the middle class represented by Jonathan Harker. Hunting down the Count is tantamount to defending the novel. This defence explains why the young solicitor never forsakes realist prose when writing his journal, though he cannot initially succeed in his task. On the one hand, he falls prisoner once he is in the castle and, as a victim of a social, sexual and psychological breakdown, he fails in narrating his experience faithfully to facts. On the other hand, his narrative alone proves insufficient to account for the events unchained by Dracula, which forces Stoker's fiction to vampirise other narrative voices.
However, the vampirisation of the novel as the genre of the bourgeoisie does not imply a formal regress to previous styles; it actually shows the crisis which that prosaic genre is undergoing in Victorian England, fed not only by forces external to the middle class but by an internal agent: the woman writer. Lucy Westerna and Mina Harker make a subversive use of writing, which is palpable in their complete and incomplete transformation into a vampire, respectively. For Lucy, writing is equated to expressing her sexual desires and, once she is a vampire, being a supernatural creature grants her the same possibility as writing does. She thus endangers the gender stereotypes of the time and the social function attributed to the novel: she is no longer the angel in the house and her written production does not serve didactic purposes. This is the reason why, to annihilate that peril, Lucy endures a second death. Mina, on the other hand, does not physically die but she undergoes a symbolic death: once Dracula has been killed, her process of vampirisation is interrupted. With this deterrent comes the death of the woman writer who manages to publish her production and enjoys both her analytical intellect and her sexuality-awakened after the Count's assault. This double condition threatens the male supremacy in both the natural and supernatural worlds. In fact, it is Mina's insightful intelligence that discloses the supernatural being's strategy of territorial expansion, making her a victim of the aristocratic vampire. Unlike Jonathan, however, she cannot rest on prose writing as an attempt to understand and organise her perceptions of the changing world around her, since that arrangement leaves her in an unprivileged position. She attempts to frame a new narrative and tries to develop a language of her own. In doing so, Mina, a self-sufficient member of the rising middle class, experiences the anxiety of authorship of the nineteenth-century woman writer. She becomes a new woman who starts to enjoy the autonomy of her written production and her sexual awakening. She is the real threat to the novel as a genre of the male bourgeoisie.

Therefore, the narrative crises explored in Dracula are related to a crisis in the conception of women, in general, and of the woman writer, in particular. In fin-de-siecle Great Britain, the imperial and industrial projects are becoming obsolete, a transformation that inevitably calls for a revision of social structures, confirmed by demonstrations in favour of the rights of workers and women. In this context, writing cannot remain oblivious to the social conflict, of which Dracula offers uncontested evidence. The novel itself forsakes the realist prose and the trust in an omniscient narrator and opts instead to narrate the adventures of a supernatural being from a multiplicity of points of view. But the supernatural creature is not just the Count Dracula. The true vampire in the novel is Mina: her analytical intelligence and her incipient sexual awakening, combined in her condition of an autonomous woman writer, are not conceived of as natural by the Victorian society. She absorbs inherited traditions related to writing and gender stereotypes only to enervate them and expose their obsolescence. She adopts a different status as a woman and as a writer. Indeed, she transforms into the New Woman and into a journalist who can carry out a diversity of tasks -interviews, description writing, transcription of conversations (Stoker, 2000, pp 46-47). Stoker's fiction achieves the same end when sapping different genres and thus exposing a crisis of literary representation of the novel as known in the eighteenth and nineteenth centuries. Mina Harker is Dracula. The formal and the gender-related threats are coded in the process of vampirisation that both the novel and the character undergo. Their conversion is averted and, consequently, the bourgeoisie, as well as its favourite prosaic genre survive by means of a deceitful strategy: Jonathan and his team turn Mina's writing against her after they leave her unprotected from the Count's attack. This assault provides vampire hunters with an 
excuse to strengthen their attempts to annihilate him. Their casuistry is exposed: when this band of men kills Dracula, they assassinate the new woman writer. She who has previously collated the narrative material into a new form of writing is restored as the angel in the house at the same time the formal experimentation of the novel is exterminated. Gender and genre conventions are reinforced. Mina and the polyphonic fragments that have fed the novel fade into silence. Dracula is closed by a single, totalising voice of a note written by Jonathan-the middleclass male narrator.

Received: 29 December 2017 Accepted: 12 April 2018

Published online: 08 May 2018

\section{References}

Arata S (1990) The occidental tourist: dracula and the anxiety of reverse colonization. Vic Stud 33(4):621-645

Auerbach E (2003) Mimesis. The representation of reality in western literature. Princeton University Press, Princeton

Bloom H (1997) The anxiety of influence: a theory of poetry. Oxford University Press, New York, Oxford

Botting F (1996) Gothic. Routledge, New York

Case A (1993) Tasting the original apple: gender and the struggle for narrative authority in dracula. Narrative 1(3):223-243

Eagleton T (2005) The English Novel. An Introduction. Blackwell, Malden

Freud S (2003) The Uncanny. Penguin Books, London

Gilbert P (2004) Mapping the victorian social body. State University of New York Press, Albany

Gilbert S, Gubar S (2000) The Madwoman in the Attic. The woman writer and the nineteenth-century literary imagination. Yale University Press, New Haven, London

Guy J (2001) The Victorian Age. An Anthology of sources and documents. Routledge, London, New York

Hopkins L (2007) Bram Stoker: a literary life. Palgrave, New York

Hurley K (2001) The Modernist Abominations of William Hope Hodgson. In: Smith A, Jeff W (eds) Gothic Modernisms. Palgrave, New York, p 129-149

Hurley K (2002) British Gothic Fiction, 1885-1930. In: Hogle JE (ed) The Cambridge Companion to Gothic Fiction. Cambridge University Press, Cambridge, New York, p 189-208

Lukács G (1971) The Theory of the Novel. The MIT Press, Cambridge

Milbank A (2002) The Victorian Gothic in English Novels and Stories, 1830-1880. In: Hogle JE (ed) The Cambridge Companion to Gothic Fiction. Cambridge University Press, Cambridge, New York, p 145-166

Moretti F (1997) Signs taken for wonder. Essays in the sociology of literary forms. Verso, London, New York

Punter D, Byron G (2004) The Gothic. Blackwell, Malden

Radick C (2013) "Complete and in Order": Bram Stoker's "Dracula" and the archival profession. Am Arch 76(2):502-520
Roth P (2010) Suddenly sexual women in bram stoker's dracula. In: Bloom H, Hobby B (eds) The Taboo.Infobase Publishing, New York, pp 23-36

Seed D (1985) The narrative method of dracula. Ninet-Century Fict 40(1):61-75

Senf C (1979) Dracula: the unseen face in the mirror. J Narrat Tech 9(3): $160-170$

Senf C (1982) Dracula: Stoker's response to the new woman. Vic Stud 26(1): 33-49

Senf C,(2017) Realism, horror and the gothic in Dracula and Thomas Hardy's "The fiddler of the reels" Pal Commun 3:17083. https://doi.org/10.1057/ palcomms.2017.83

Strandberg V (1964) The crisis of belief in modern literature. Engl J 7(53):475-483 $+544$

Stoker B (2000) Dracula. Wordsworth Editions, Hertfordshire

Watt I (1959) The rise of the english novel. Studies in Defoe, Richardson and Fielding. University of California Press, Berkeley and Los Angeles

Wicke J (1992) Vampiric typewriting: Dracula and its Media. ELH 59(2):467-493

Woolf V (2008) Professions for women. Selected Essays. Oxford University Press, New York, p 140-145

\section{Data availability}

Data sharing is not applicable to this article as no datasets were generated or analysed during this study.

\section{Acknowledgements}

The author thanks Florencia Carrió and Marianne Hewitt for their careful reading and insightful comments.

\section{Additional information}

Competing interests: The author declares no competing interests.

Reprints and permission information is available online at http://www.nature.com/ reprints

Publisher's note: Springer Nature remains neutral with regard to jurisdictional claims in published maps and institutional affiliations.

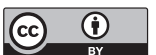

Open Access This article is licensed under a Creative Common Attribution 4.0 International License, which permits use, sharing, adaptation, distribution and reproduction in any medium or format, as long as you give appropriate credit to the original author(s) and the source, provide a link to the Creative Commons license, and indicate if changes were made. The images or other third party material in this article are included in the article's Creative Commons license, unless indicated otherwise in a credit line to the material. If material is not included in the article's Creative Commons license and your intended use is not permitted by statutory regulation or exceeds the permitted use, you will need to obtain permission directly from the copyright holder. To view a copy of this license, visit http://creativecommons.org/ licenses/by/4.0/.

(C) The Author(s) 2018 